\title{
Probiotic properties and exopolysaccharides production of Stretptococcus thermophilus CNRZ 447 and Enterococcus durans NCBI 53345
}

\section{Badra Boubakeur ${ }^{1}$, Hafidha Khadem ${ }^{1}$, Moustapha Sangalo Drabo ${ }^{2}$, Ahmad Ali ${ }^{3}$, Aicha Tirtouil Meddah ${ }^{4}$}

\author{
1 - Ibn Khaldoun University, Tiaret, Algeria \\ 2 - Ouagadougou University, Ouagadougou, Burkina Faso \\ 3 - Mumbai Vidyanagari University, Mumbai, India \\ 4 - Mustapha Stambouli University, Mascara, Algeria
}

Keywords:
Probiotic
Resistance
Exopolysaccharide
S. thermophilus
E. durans

Article history:

Received

29.05.2021

Received in revised form 16.09.2021

Accepted

30.12.2021

\section{Corresponding author:}

Badra Boubakeur E-mail:

badra.boubakeur@ univ-tiaret.dz

DOI:

$10.24263 / 2304-$ 974X-2021-10-4-17

\section{Abstract}

Introduction. The aim of the present study was investigation of probiotic and technological properties of Streptococcus thermophilus CNRZ 447 and Enterococcus durans NCBI 53345.

Materials and methods. The characterization tests were carried out in batches with different conditions of $\mathrm{pH}$ (2 and 3$)$, temperature (15, $37,45,50,60$ and $\left.65^{\circ} \mathrm{C}\right)$, bile salts $(0.3,0.5$ and $1 \%)$, and antibiotics $\left(\mathrm{C}_{10}, \mathrm{GM}, \mathrm{AN}_{30}\right.$ and $\left.\mathrm{TE}_{30}\right)$. The antagonistic effect was realized against $E$. coli and $S$. aureus. The bacterial adhesion and exopolysaccharide production were performed under optimized cultivation conditions. The exopolysaccharide were then profiled by HPLC using the Agilent LC 1260 system coupled with refractive index detector.

Results and discussion. The strains have proven a considerable ability to persist in vitro under conditions simulating the human gastrointestinal tract. They survied at $\mathrm{pH} 2$ and 3 for $3 \mathrm{~h}$ of incubation. Only a minimal reduction of $1 \%$ and $0.99 \log$ cfu was reported for both bacterial strains $S$. thermophilus and $E$. durans at $\mathrm{pH}$ 2. A small reduction in the strains growth was noted in presence of bile salts at different concentrations (the discount rates recorded were between 1 and $3 \%$ ), revealing their ability to survive through the gastrointestinal tract. A significant tolerance of temperature variation was also noted. The ideal temperatures for the $E$. durans and $S$. thermophilus growth were respectively $37^{\circ} \mathrm{C}$ and $45^{\circ} \mathrm{C}$. The auto-aggregation rates registered after $4 \mathrm{~h}$ of decantation are 76 and $51 \%$ for $S$. thermophilus and $E$ durans, respectively. Surface hydrophobicity of $81 \%$ and $61 \%$ for $S$. thermophilus and $E$. durans, antagonistic capacity against $E$. coli and $S$. aureus, and antibiotic resistance has been recorded. S. thermophilus was resistant to 3 of 4 antibiotics tested. Meanwhile E. durans was resistant to tetracycline and nalidixic acid. An appreciable production of exopolysaccharides was noticeable. E. durans was more prolific in exopolysaccharides (ESP) production than S. thermophilus $(1661 \pm 27$ $\mathrm{mg} / \mathrm{L}$ vs $176 \pm 4 \mathrm{mg} / \mathrm{L}$ ). The EPS produced by $S$. thermophilus CNRZ 447 was primarily composed of two triholosides that consisted predominantly of glucose. Analysis of $E$. durans EPS yielded peaks at 7 and 9 min representing oligosaccharides, and a single peak eluting at $20.4 \mathrm{~min}$, which is presumably sorbitol.

Conclusion. The tested strains have demonstrated promising probiotic potential and high exopolysaccharide production. 


\section{Introduction}

The food preservation time can be prolonged due to the antagonistic and/or antimicrobial activity of microorganisms performing the fermentation. Lactic acid bacteria are the most commonly encountered bacterial group in traditional fermented foods (Bogsan et al., 2015). The protective role of lactic acid bacteria against pathogens, their GRAS (Generally Recognized as Safe) character, and the diversity of their pharmaceutical and technological metabolites have received great attention (Kos et al., 2003). They have traditionally been associated with food and feed fermentations, and are generally classified in the technological flora and considered as beneficial microorganisms. Their exploitation in the fermentation industry is widely developed, aiming essentially the establishment of more efficient starter cultures. However, some genera (Streptococcus, Lactococcus, Enterococcus, and Carnobacterium) may also include species or strains that are recognized human or animal pathogens (FAO, 2001; Kos et al., 2003). A thorough understanding of the taxonomy, metabolism, and molecular biology of lactic acid bacteria is therefore necessary to fully utilize the technological, nutritional, and health aspects of these bacteria while avoiding potential risks.

The development of the food industry and in particular the use of new raw materials, as well as the need to create new high-quality products without the addition of plant or animal texturizing and stabilizing compounds, explain the increased interest in this diverse group of bacteria and their metabolites responsible for the nutritional properties acquisition or the foods sensorial and sanitary quality. The use of probiotic lactic acid bacteria is not only limited to improving the sensory properties of foods, but they are also involved in various applications, such as preparation of functional foods, vaccines, and pharmaceuticals, which requires the selection of robust lactic acid bacteria. The main selection criteria are resistance during food processing and production (e.g., cold and heat resistance). Probiotic lactic acid bacteria are also expected to be resistant enough to survive in the digestion process and reach the consumer's colon alive, where they may have various health effects. Adhesion and autoaggregation capacity of probiotic strains also appear to be necessary criteria for attachment to intestinal epithelial cells, and the ability to co-aggregate may provide a barrier that prevents colonization by pathogenic microorganisms (Boubakeur et al., 2018; O'Grady and Gibson, 2005; Gregirchak et al., 2019). Regarding the technological aspect, the adhesion properties and the propensity to form biofilm represent important attributes enabling a more effective production of technological interest metabolites, as in case of exopolysaccharides (EPS) (Kos et al., 2003).

In this context, the main objective of the present study was to investigate the technological and probiotic attributes of two lactic bacteria, Streptococcus thermophilus CNRZ 447 and Enterococcus durans NCBI 53345.

\section{Materials and methods}

\section{Lactic acid strains}

The lactic acid bacteria used in the present study were chosen for their potential technological interest, especially in the food industry. S. thermophilus CNRZ 447 was obtained from the collection of microorganisms of the National Center of Zootechnical Research INRA "Rennes-France". E. durans was subsequently isolated among several lactic strains from a locally consumed fermented product known as "Hamoum" (Drabo et al., 2019). 
It was phenotypically identified following the procedures described by Cowan (2004). Isolation on the selective media (MRS, M17) generated two bacterial species with overlapping biochemical and microscopic characteristics. Hence, the latter were identified based on their proteomic spectra by Mass Spectrometry-Matrix-Assisted Laser Desorption Ionization-Time Of Flight (MS-MALDI-TOF) (Pavlovic et al., 2013). Isolate aliquots were performed on MRS and M17 selective agar and were delivered in a coolbox to the Center for Scientific and Technical Research in Physical and Chemical Analysis (CRAPC-Algeria). The identification was carried out using the MALDI Biotyper software.

\section{Inocula preparation}

To confirm the strain's purity, culture was grown on M17 agar, in aerobic conditions at $42{ }^{\circ} \mathrm{C}$. Before each test, an overnight culture was prepared. Colonies were recovered with a Pasteur pipette and suspended in sterile physiological solution. Suspensions were adjusted to an optical density (OD) of 0.11 (corresponds to $10^{8} \mathrm{CFU} / \mathrm{mL}$ ) at a wavelength of $578 \mathrm{~nm}$ (BIOCHROM Libra S6) (Andrew et al., 2008).

\section{Assessment of strains probiotic and technological potential}

Typical methods for in vitro determination of probiotic potential include low $\mathrm{pH}$ tolerance, bile salts tolerance, antibiotic susceptibility, antimicrobial activity, and adhesion capacity (Mulaw et al., 2019).

Survival in gastric juice similar solution. The test was performed according to the method described by Charteris et al. (1998) with some modifications. A solution similar to gastric juice was freshly prepared by suspending $0.3 \%$ pepsin in $0.5 \%$ sterile saline, the $\mathrm{pH}$ of the solution was then adjusted to $\mathrm{pH} 2$ and $\mathrm{pH} 3$. An $18 \mathrm{~h}$ culture was centrifuged at $6000 \mathrm{~g}$, $20 \mathrm{~min},+5^{\circ} \mathrm{C}$, then washed 3 times in PBS $(0.1 \mathrm{M}, \mathrm{pH}$ 7). The recovered pellet was dissolved in $3 \mathrm{~mL}$ of PBS, and then $1 \mathrm{~mL}$ of this suspension was collected by centrifugation $(12000 \mathrm{~g}$, for $5 \mathrm{~min}$, at $+5 \mathrm{C}^{\circ}$ ) and added to the gastric juice-like solution at $\mathrm{pH} 2$ and $\mathrm{pH} 3$. The ODs were determined at $575 \mathrm{~nm}$ before and after incubation for $3 \mathrm{~h}$ at $+37^{\circ} \mathrm{C}$.

Tolerance to bile salt. The tolerance of both strains to bile salts was assessed by adopting the modified protocol of Anukam and Koyama (2007). $1 \mathrm{~mL}$ of $10^{7} \mathrm{CFU} / \mathrm{mL}$ inocula were added into $0.3,0.5$ and $1 \%$ bile M17 medium. ODs were measured at $575 \mathrm{~nm}$ after $24 \mathrm{~h}$ of incubation at $+37^{\circ} \mathrm{C}$. The growth inhibition percentage (GI \%) in bile salts presence was calculated according to the following formula:

GI $\%=\left[\left(\log N_{0}-\log \mathrm{N}_{\mathrm{t}}\right) / \log \mathrm{N}_{0}\right] \times 100$. Where $\mathrm{N}_{0}$ is a viable cell number in M17 broth without bile salts after $3 \mathrm{~h}$ of incubation and $\mathrm{N}_{\mathrm{t}}$ is a viable cell number in M17 broth containing bile salts after $3 \mathrm{~h}$ of incubation.

Acid pH tolerance. Tolerance to low $\mathrm{pH}$ was tested as described by Anukam and Koyama (2007), with some modifications; M17 broth was adjusted to $\mathrm{pH} 2$, $\mathrm{pH} 3$, by addition of $\mathrm{HCl}(1 \mathrm{~N})$, and then inoculated with $1 \mathrm{~mL}$ of an $18 \mathrm{~h}$ culture $\left(10^{8} \mathrm{CFU} / \mathrm{mL}\right)$. ODs were determined at $578 \mathrm{~nm}$ and were compared to the control at $\mathrm{pH} 7$ after $3 \mathrm{~h}$ of incubation.

Optimal temperature, thermotolerance, and lethal temperature. The growth optimal temperatures of the two bacterial strains, their thermotolerance, and low-temperature resistance were determined according to the method described by Haddaji et al. (2015) with some modifications. A suspension $\left(10^{8} \mathrm{CFU} / \mathrm{mL}\right)$ from an $18 \mathrm{~h}$ fresh culture was added into a series of tubes containing M17 broth. The tubes series were then incubated at different temperatures: $+15^{\circ} \mathrm{C},+37^{\circ} \mathrm{C},+45^{\circ} \mathrm{C},+50^{\circ} \mathrm{C}$ for $24 \mathrm{~h}$. The tubes serving for the thermoresistance test were incubated at $+60^{\circ} \mathrm{C}$ and $+65^{\circ} \mathrm{C}$ for 120 and 90 min respectively. ODs were read at $578 \mathrm{~nm}$. 
Adhesion capacity "hydrophobicity and auto-aggregation". The aggregation capacity was performed according to the method of Kos et al. (2003). Bacterial biomass from $18 \mathrm{~h}$ fresh cultures were recovered by centrifugation at $5000 \mathrm{~g}$ for $15 \mathrm{~min}$ and washed three times in PBS. Then the cells suspension were adjusted to a final charge of $10^{8} \mathrm{CFU} / \mathrm{mL}$ and distributed in two tubes series at $4 \mathrm{ml}$. The tubes were decanted for $5 \mathrm{~h}$, and every hour 0.1 $\mathrm{mL}$ of the culture taken from the surface of each tube and was transferred to another tube containing $3.9 \mathrm{~mL}$ of PBS. ODs were measured at $578 \mathrm{~nm}$, and the results were expressed as a percentage according to the following formula: \% Autoaggregation=1-( $\left.\mathrm{A}_{t} / \mathrm{A}_{0}\right) \cdot 100$; where $A_{t}$ : the suspension OD after $1 \mathrm{~h}, 2 \mathrm{~h}, 3 \mathrm{~h}, 4 \mathrm{~h}, 5 \mathrm{~h}$ decantation, $\mathrm{A}_{0}$ : the suspension OD at t0. For the hydrophobicity test, bacterial biomasses of both strains were harvested from the $24 \mathrm{~h}$ cultures, washed once with PBS and adjusted to $10^{8} \mathrm{CFU} / \mathrm{mL}$ in $\mathrm{KNO}_{3}\left(0.1 \mathrm{~mol} . \mathrm{1}^{-1}\right) .3$ $\mathrm{mL}$ of each bacterial suspension was added to $1 \mathrm{~mL}$ of each solvent (xylene, ethyl acetate, and chloroform). The mixtures were incubated for $10 \mathrm{~min}$ at room temperature and then shaken rigorously for $2 \mathrm{~min}$. The ODs of the aqueous phase were measured after a $20 \mathrm{~min}$ decantation. The solvent adhesion percentage was calculated according to the following formula:

$$
\% \text { Solvent adhesion }=\left(1-\frac{A_{t}}{A_{0}}\right) \times 100
$$

where $A_{t}$ - the aqueous phase OD after 20 min decantation, $A_{0}$ - the suspension OD at $t_{0}$.

Antibiotic resistance. Antibiotic resistance was investigated by adopting the disc diffusion method described by Bauer (1966). total of four antibiotics were tested: nalidixic acid $(30 \mu \mathrm{g})$, chloramphenicol $(30 \mu \mathrm{g})$, gentamicin $(10 \mu \mathrm{g})$, tetracycline $(30 \mu \mathrm{g})$. The diameters of the inhibition zones $(\mathrm{mm})$ were measured after incubation for $24 \mathrm{~h}$ at $+37^{\circ} \mathrm{C}$.

Antagonistic effect. The antagonistic effect of lactic strains was tested against two pathogenic strains, Escherichia coli (ATCC 25922) and Staphylococcus aureus (ATCC 25923), by adopting the cross streak technique described by Balouirin et al. (2016); the lactic acid bacterial strain was streaked in the center of the agar plate. After incubation, the agar was streaked with the pathogenic strains in single streaks perpendicular to the central streak. After a second incubation, the antimicrobial interactions were analyzed by determining the inhibition zones and the inhibition percentage according to the following formula:

$$
\% \text { inhibition percentage }=\left(\frac{\text { Inhibitory diameter }(\mathrm{mm})}{\text { Petri dish diameter }}\right) \times 100
$$

Production and recovery of exopolysaccharides. Bacterial cultures were grown under the optimal conditions determined earlier. The extraction of EPSs and their purification was performed by adopting the protocol described by Oleksy-Sobczak and Klewicka( 2019) with some modifications. After incubation, the series of tubes containing the bacterial cultures were placed in a water bath at $+80^{\circ} \mathrm{C}$ for $15 \mathrm{~min}$, with shaking every $5 \mathrm{~min}$, to release the wall-attached EPSs. Then, the cultures were passed through a millipore filter $(0.45 \mu \mathrm{m})$, to remove the bacterial cells and to recover a filtrate. Three volumes of ethanol at $-80^{\circ} \mathrm{C}$ were added to this filtrate, and the tubes were stored at $-18{ }^{\circ} \mathrm{C}$ overnight. The EPSs were precipitated and recovered by cryocentrifugation $\left(12000 \mathrm{~g}\right.$ for $20 \mathrm{~min}$ at $\left.+4{ }^{\circ} \mathrm{C}\right)$ three times and solubilized in sterile distilled water.

Exopolysaccharides quantification. The quantification of EPSs was performed according to the total sugars technique of Dubois (1956).

HPLC characterization of the produced EPSs. The EPS produced by each of the two strains was identified by HPLC (Agilent LC 1260). Briefly, 100 $\mu$ of solubilized biopolymer was added to $200 \mu \mathrm{l}$ of HCL (2M) and sonicated in a thermostatically controlled bath at 45 


\section{— Biotechnology. Microbiology -}

min, then subjected to continuous shaking. A volume of acid-hydrolyzed EPSs was made up to $1 \mathrm{~mL}$ with an eluent of $80 \%$ acetonitrile and $20 \%$ water. A $300 \mu \mathrm{L}$ volume of crude extract was also mixed with the eluent. The extracts were filtered $(0.22 \mu \mathrm{m})$, and a volume of $10 \mu \mathrm{L}$ was injected. The crude and hydrolyzed extracts were analyzed on an Agilent Zorbax Carbohydrate analysis column $(4.6 \times 150 \mathrm{~mm}, 5 \mu \mathrm{m})$. The column flow rate was $1.3 \mathrm{~mL} / \mathrm{min}$, and the operating temperature was $+30^{\circ} \mathrm{C}$.

\section{Data processing}

All tests were performed in duplicate, and the data were analyzed by one-way analysis of variance (ANOVA) and means were compared using the Turkey HSD (Honest Significance Difference) post hoc test $(\mathrm{P} \leq 0.05)$. All statistical tests were performed using the R program (version 3.6.1).

\section{Results and discussion}

\section{Enterococcus durans: isolation and identification}

Several lactic and non-lactic bacteria were isolated from the fermented food "Hamoum" (Drabo et al., 2019). Strains which colonies had mucous appearance indicating that these strains produce exopolysaggharides were chosed for further study. A purification step on M17 agar, after a succession of subcultures, resulted in colonies with the same appearance, whose phenotypic identification (cultural, microscopic, and biochemical characters), was done following the assortment table described by Cowan (2004). The results of the phenotypic identification are presented in Table 1.

Phenotypic identification of $E$. durans

Table 1

\begin{tabular}{|l|c|}
\hline Profil & Result \\
\hline Cultures Conditions & $\mathrm{M} 17\left(\mathrm{O}_{2}, 37{ }^{\circ} \mathrm{C}, 24 \mathrm{~h}\right)$ \\
\hline Colony appearance & Translucent \\
\hline Gram & +/ Single cocci, pairs, tetrads, and chains \\
\hline Catalase & - \\
\hline Oxydase & + \\
\hline Mannitol / Mobility & $-/-$ \\
\hline ONPG & + \\
\hline Simmons' Citrate & - \\
\hline Proteolysis & +++ \\
\hline ADH/LDH/ODC & $+/-/-$ \\
\hline Identification & E. durans/ Pediococcus spp. \\
\hline
\end{tabular}

After biochemical identification, the isolate was characterized by MS-MALDI-TOF (Figure 1), the strain isolated was presumed to be Enterococcus durans. 


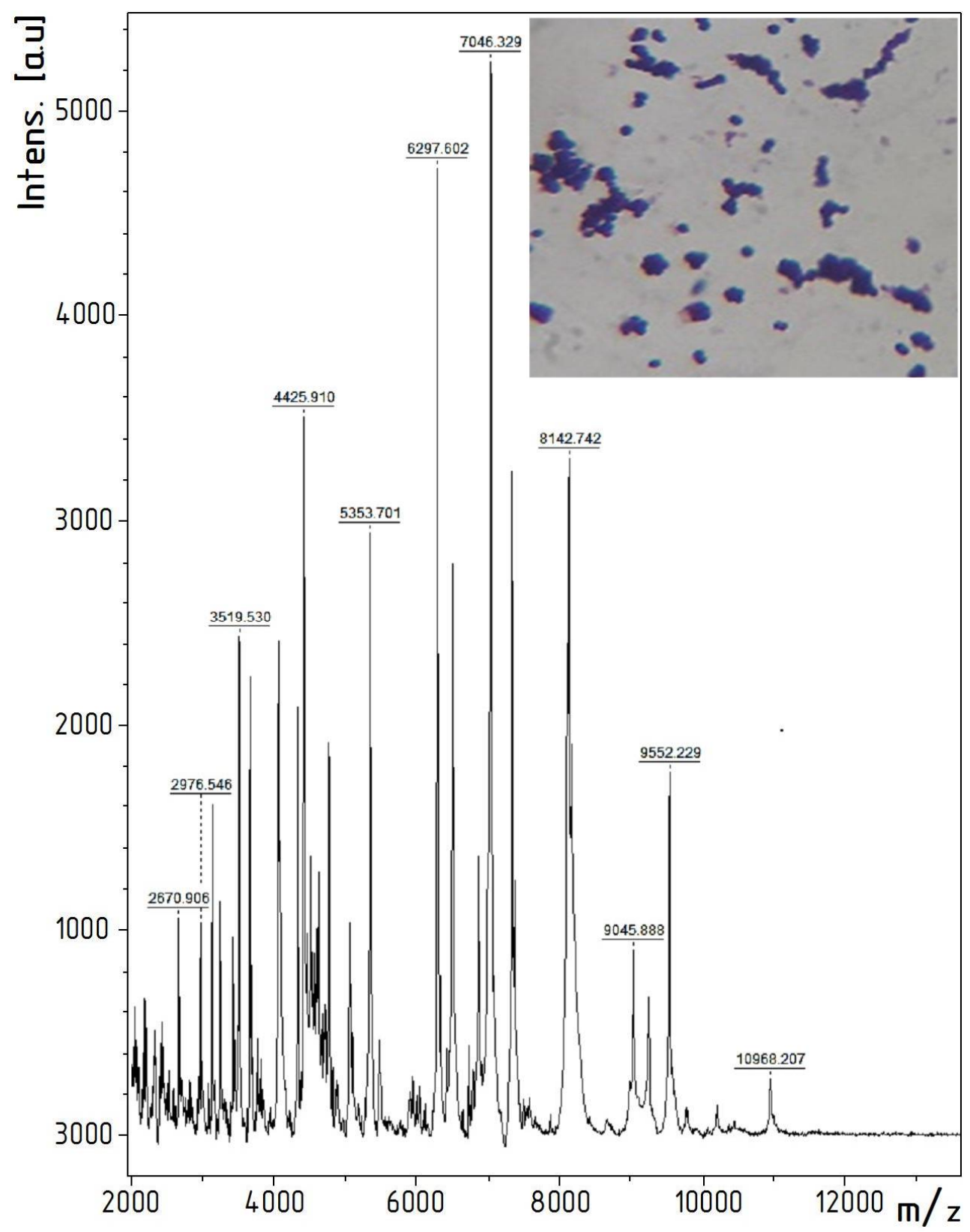

Figure 1. MALDI-TOF spectra of Enterococcus durans 


\section{Evaluation of the probiotic potential of $S$. thermophilus and $E$. durans}

Growth, resistance to environmental variations, adhesion and biofilm formation are phenomena that enable microorganisms to colonize a habitat and to maintain themselves there, provide species with an ecological, technological, and sanitary advantage microbial cells are directly in contact with their substrate which avoids the diffusion of enzymes in the external environment (Akers et al., 2015)

Growth at different temperatures/thermoresistance. Stress due to temperature variation, is probably, the most common that bacteria and other organisms face in the natural world (Varmanen and Savijoki, 2011). Figure 2, shows the effect of temperature, on the growth and viability of both lactic strains. It was well shown that the temperature values of $37{ }^{\circ} \mathrm{C}$ and $45^{\circ} \mathrm{C}$ are the most ideal for the growth of E. durans and $S$. themophilus and correspond to the cell concentrations of $9.08 \log \mathrm{CFU} / \mathrm{mL}$ and $9.05 \log \mathrm{CFU} / \mathrm{mL}$, respectively. The growth of $E$. durans at a low temperature of $+15^{\circ} \mathrm{C}$ was reduced, however, the reduction was not significant $(\mathrm{P}>0.05)$ for $S$. thermophilus, and a reduction of $0.3 \log 10$ was noted at $+15^{\circ} \mathrm{C}$. The optimal temperatures recorded for both strains were $+37^{\circ} \mathrm{C}(37 \mathrm{vs}$ $45: \mathrm{P}=0.411, \mathrm{P}>0.05 ; 37$ vs $15: \mathrm{P}=0.00001, \mathrm{P}<0.001 ; 37$ vs $50:: \mathrm{P}=0.000003, \mathrm{P}<0$. 001 ) for E. durans and $+45^{\circ} \mathrm{C}(45$ vs $15: \mathrm{P}=0.23, \mathrm{P}>0.05 ; 45$ vs $37: \mathrm{P}=0.193, \mathrm{P}>0.05$; 45 vs $50: \mathrm{P}=0.01, \mathrm{P}<0.05 ; 45$ vs $60: \mathrm{P}=0.000006, \mathrm{P}<0.001)$ for $S$. thermophilus. A minimal growth rate at $+50{ }^{\circ} \mathrm{C}$ was noted for both strains. A small but very highly significant $(\mathrm{P}<0.001)$ reduction in growth rates at $+60{ }^{\circ} \mathrm{C}$ and $+65{ }^{\circ} \mathrm{C}$ during $2 \mathrm{~h}$ of incubation was recorded, 1.69 and $1.68 \log \mathrm{cfu} / \mathrm{mL}$ for $E$. durans and 1.48 and $1.44 \log \mathrm{cfu} / \mathrm{mL}$ for $S$. thermophilus. Auffray et al (1995) reported that $S$. thermophilus grew at temperatures ranging from 20 to $52{ }^{\circ} \mathrm{C}$ and was able to acquire thermotolerance when subjected to heat shock. They recorded survival rates of $1 \%$ and $0.1 \%$ at $58{ }^{\circ} \mathrm{C}$ for 15 and $30 \mathrm{~min}$ respectively. The low growth when the temperature was switched from +42 to $+52{ }^{\circ} \mathrm{C}$ was attributed to the protein synthesis profile of $S$. thermophilus, which showed a decrease in the synthesis of many polypeptides, thus indicating inhibition of protein synthesis due to the temperature change. Fang et al (2002), on the other hand, reported that exposure to a low temperature of $+5{ }^{\circ} \mathrm{C}$ for 15 days did not affect the survival of $S$. thermophilus. They noted high survival rates at $10^{\circ} \mathrm{C}$ for $2 \mathrm{~h}$ and $4 \mathrm{~h}$ and at $+15^{\circ} \mathrm{C}$ for $2 \mathrm{~h}$. Růžičková et al. (2020) reported that due to their adaptability, species of the genus Enterococcus survive in various environments. Thus, for the majority of species, the optimal temperature is between +35 and $+37{ }^{\circ} \mathrm{C}$, however, a few species thrive at $+45{ }^{\circ} \mathrm{C}$ and even at low temperatures around $+10{ }^{\circ} \mathrm{C}$. Exposure to a brief heat shock with a temperature at or slightly above the normal growth range provides cells the ability to acquire resistance to a lethal heat shock due to a higher temperature (Jobin et al., 1998). Indeed, in response to sudden temperature fluctuations, living organisms respond with rapid changes in gene expression, resulting in the massive synthesis of a group of proteins called heat shock proteins (HSPs) (Lim and Gross, 2011). This synthesis notes a universal phenomenon occurring in most organisms. Even though HSPs are present in different bacteria, the heat shock response reflects the amazing diversity of bacterial gene regulation in various bacteria, including lactic acid bacteria (Auffray et al., 1995). 


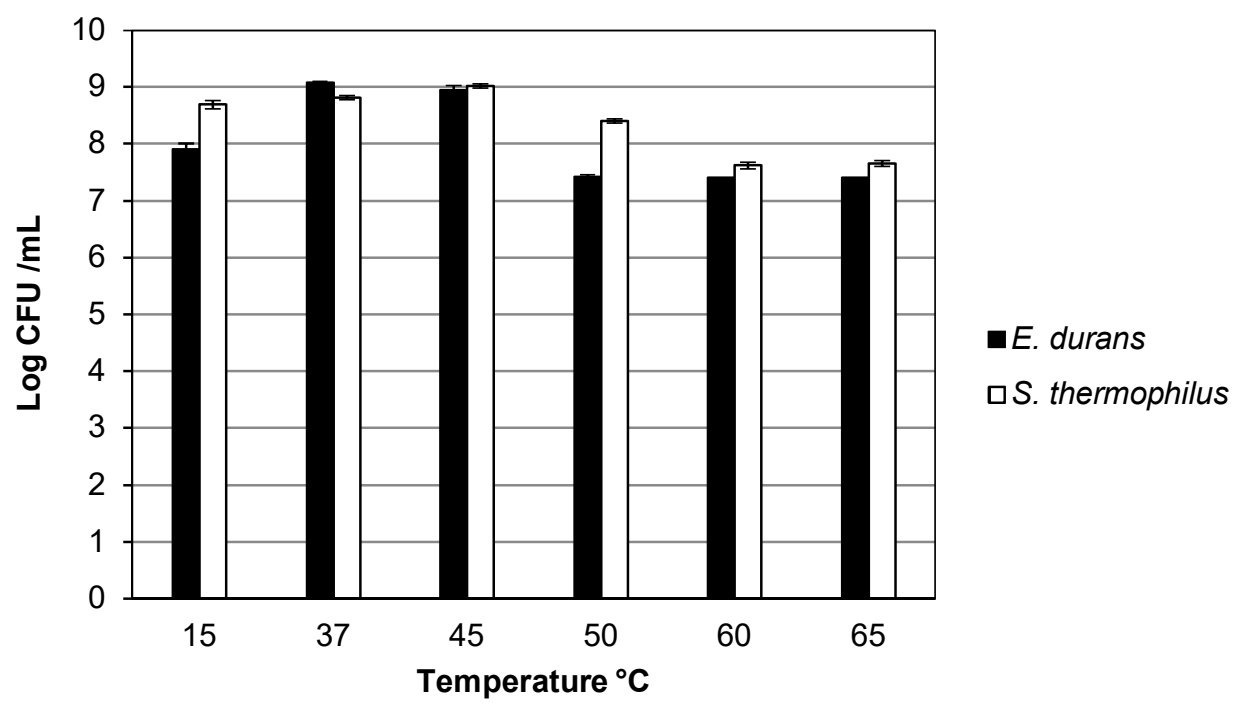

Figure 2. Temperature effect on the growth and viability of both lactic strains.

Resistance to $\mathbf{p H}$. An important characteristic of probiotic lactic acid bacteria used as adjuvants is their tolerance of bile and resistance to gastric juices. Although the degree of tolerance required for maximum growth in the GIT is not determined, the selection of species with improved acid resistance appears to be judicious (Dressman et al.,1990) . Under fasting conditions, the accepted $\mathrm{pH}$ value of gastric juice is in the vicinity of 2 (Nami et al., 2019). Therefore, this $\mathrm{pH}$ has been used as a standard for in vitro tests, evaluating the survival of probiotic cultures in the human stomach (Nami et al., 2019). According to the results displayed in Table 2, $\mathrm{pH}$ variations significantly affected the growth of both strains $(\mathrm{P}<0.001)$, they were able to survive at acid $\mathrm{pH}$, a slight reduction compared to the control was recorded at $\mathrm{pH}=2$ after $3 \mathrm{~h}$ of incubation, in the order of 1.0 and $0.99 \log \mathrm{cfu} / \mathrm{mL}$ for $S$. thermophilus and $E$. durans respectively. At $\mathrm{pH}=3$, the reduction in survival rate was in the order of 1 and $0.15 \log \mathrm{cfu} / \mathrm{mL}$ for $S$. thermophilus and E. durans respectively, E. durans appears to be more tolerant.

The tolerance of $E$. durans strain to acidic conditions was also studied by Nami et al. (2019) who demonstrated that Enterococcus isolates could be excellent candidates for the production of functional foods to promote health due to their high tolerance of low $\mathrm{pH} 2.5$, especially E. durans ES11, ES20 and ES32.

However, Boke et al. (2010) observed a considerable reduction in viability at $\mathrm{pH} \leq 3.0$, for all strains tested, including $S$. thermophilus, the sensitivity to acid is greater for strains with low EPS production. According to this study, the resistance of some lactic strains to stressful conditions (acidic $\mathrm{pH}$ ) can be explained by the fact that these bacteria are producers of EPS, and that these polymers could play a protective role. Lactic acid bacteria are equipped with stress sensing systems to activate defenses, allowing them to readapt to difficult conditions or environmental changes. DNA repair mechanisms can also be characterized in these bacteria as a response to oxidative stress and acidic stress (Chen et al., 2019). 
Growth at acid pH

\begin{tabular}{|c|c|c|c|}
\hline & $\begin{array}{c}\text { Time } \\
\text { (h) }\end{array}$ & E. durans $(\log$ CFU/mL) & S. thermophilus $(\log$ CFU/mL) \\
\hline \multicolumn{4}{|c|}{ Digestion in a solution simulating gastric juice } \\
\hline $\mathrm{pH} 2$ & 0 & $8.225 \pm 0.00$ & $8.245 \pm 0.005$ \\
& 3 & $7.233 \pm 0.002$ & $7.225 \pm 0.028$ \\
\hline $\mathrm{pH} 3$ & 0 & $7.164 \pm 0.016$ & $8.3 \pm 0.011$ \\
& 3 & $7.018 \pm 0.018$ & $7.305 \pm 0.005$ \\
\hline \multicolumn{4}{|c|}{ Medium with acid pH } \\
\hline $\mathrm{pH} 2$ & 0 & $7.477 \pm 0.00$ & $7.477 \pm 0.00$ \\
& 3 & $8.365 \pm 0.005$ & $8.37 \pm 0.00$ \\
\hline \multirow{2}{*}{ pH 3 } & $\mathbf{0}$ & $\mathbf{7 . 4 7 7} \pm \mathbf{0 . 0 0}$ & $\mathbf{7 . 4 7 7} \pm \mathbf{0 . 0 0}$ \\
& $\mathbf{3}$ & $\mathbf{8 . 3 9 5} \pm \mathbf{0 . 0 1 7}$ & $\mathbf{8 . 4 \pm 0 . 0 0}$ \\
\hline
\end{tabular}

Growth in the presence of increasing concentrations of bile salts. Lactic acid bacteria being the most representative probiotics, which are used in the production of dairy products, and vegetable-based foods. Bile tolerance is a crucial property, commonly consistent with the growing ability of bacteria that act as probiotics (Begley et al., 2005). Figure 3 illustrates the response of the studied strains to increasing concentrations of bile salts. Both strains survive in the bile salts presence, without substantial reduction (1 to $3 \%$ ). The viability percentage of $S$. thermophilus was comparable to that of the control, namely $99 \%, 98 \%$ and $96 \%$ for bile salts concentrations of $0.3,0.5,1 \%$ respectively. The tolerance of E. durans to different bile salts concentrations was much higher than that of $S$. thermophilus, and the viability rates recorded were even higher than those of the control, preserving $100 \%$ of the initial population. Bile is a digestive secretion involved in the fats emulsification and solubilization process in the human digestive tract. This secretion can affect the phospholipids and proteins of the cell membranes and thus disrupt cell homeostasis.

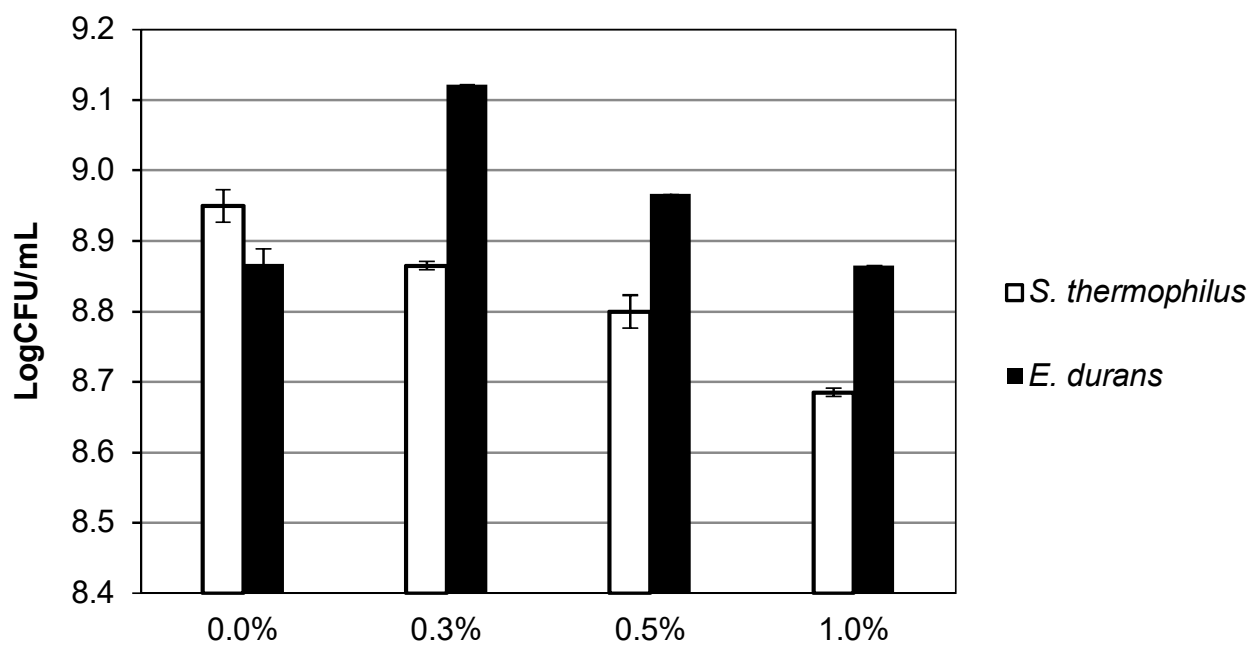

Bile salts concentratins, $\%$

Figure 3. Growth in the presence of bile salts 
It is therefore crucial for probiotics to be able to tolerate bile for surviving and colonizing the gastrointestinal tract. Indeed, it is recommended to use bile salts concentrations of $0.15-0.3 \%$ for the probiotic bacteria selection (Boke et al., 2010). Tuncer and Tuncer (2010) proved viability maintenance of S. thermophilus ST 8.01 after $24 \mathrm{~h}$ incubation in the presence of $0.3,0.5$, and $1 \%$ bile salts. The highest inhibition percentage was recorded at 1\%. In contrast, Vinderola and Reinheimer, 2003), reported low resistance of $S$. thermophilus strains in the presence of bile salts. Pieniz et al. (2014), showed that the survivability of $E$. durans LAB18s was maintained in the presence of all tested bile salts concentrations (up to 1.5\%). However, Li et al. (2020), estimated the survival rate of $E$. durans at $56 \%$ in the presence of $0.3 \%$ bile. Thus, strains producing more EPS exhibited a significant protective effect against bile salts (0.3\%). Furthermore, Bagci et al. (2019), evaluating the probiotic characteristics of Enterococcus genus strains isolated from human milk and colostrum, showed that these isolates exhibited high tolerance to acids (up to $\mathrm{pH}$ $3.0)$ and bile $(0.5 \%)$, suggesting their strong ability to survive in the upper gastrointestinal tract.

Aggregation capacity. The aggregation capacity is an important factor in the colonization of the gut by probiotics thus preventing the adhesion of pathogens (Lee et al., 2008). The percentages of cells aggregation of the bacterial strains are displayed in Figure 4.

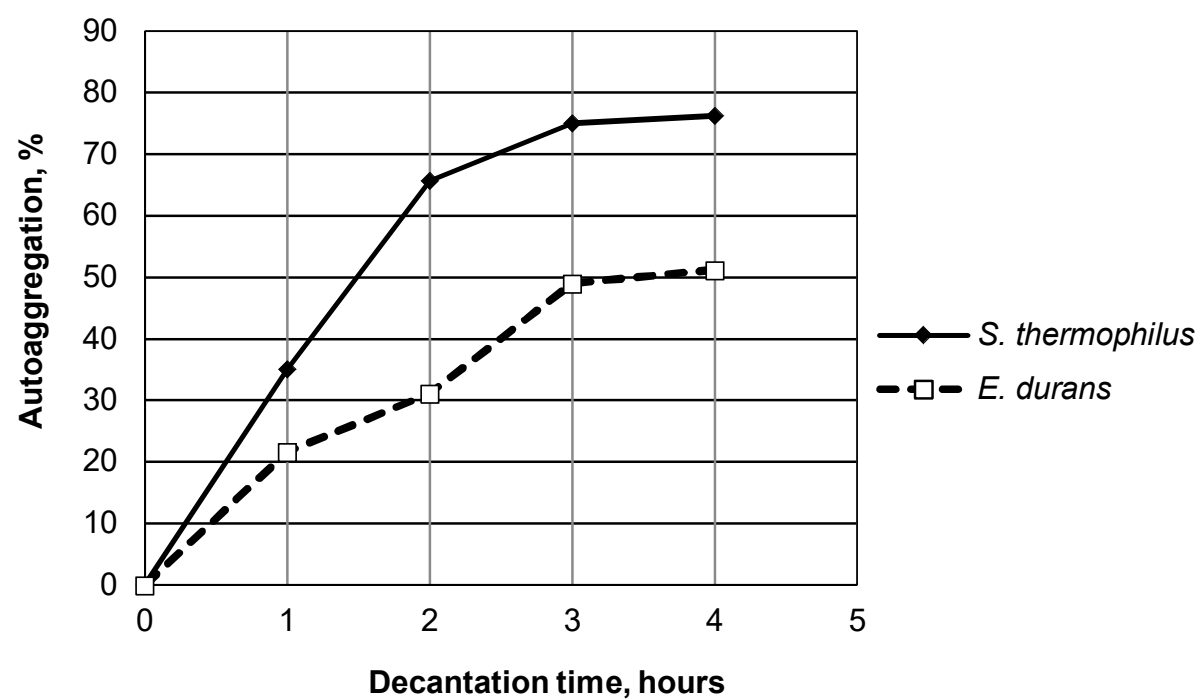

Figure 4. Adhesion level of the two strains.

The autoaggregation percentages were increased in parallel with the prolongation of the decantation time for both strains $(\mathrm{P}<0.05)$ they vary from 35 to $76 \%$ and from 21 to $51 \%$ for $S$. thermophilus and $E$. durans, respectively. The autoaggregation capacity recorded by $S$. thermophilus after $4 \mathrm{~h}$ of incubation was greater than that of $E$ durans for the same duration (76\% vs $51 \%$, p-values $\leq 0.05)$. Tuncer and Tuncer (2014) reported that the aggregation percentage recorded for $S$. thermophilus ST8.01 was $49.55 \pm 6.24 \%$. On the other hand, Lee 
et al. (2008) recorded for an E. durans isolate an autoaggregation rate in the vicinity of 50\%. Furthermore, in their study on the estimation of the adhesive power of probiotics, Xu et al. (2009) noted that the autoaggregation capacity of probiotic strains is higher than those of pathogens. They reported that the autoaggregation values displayed by probiotic strains ranged from $36 \%$ to $51 \%$. The cell aggregation process is based on an interaction between cell surface elements such as lipoteichoic acids, lectin-like proteins, as well as soluble proteins and pheromones (Boris et al, 1997), it can be a kind of host defense against infections. Besides, probiotics adhere differently, thus it is a trait that depends on the strain and the characteristics of the cell surface, namely hydrophobicity and extracellular protein profile Collado, 2009; Ayyash et al., 2018)

Adhesion to solvents. The hydrophobic potential of the cell surface of probiotics is a criterion to determine their adhesion to intestinal epithelial cells. More hydrophobic properties might provide probiotics having a competitive position (Bagci et al., 2019; TerzićVidojević et al., 2015) allowing the colonization of the human gastrointestinal tract and expression of their benefits; however, some studies have demonstrated that hydrophobicity is not at all a unique factor governing the adhesion of microbes to the cell surface (Bagci et al., 2019). The two strains' affinity to solvents is reported in Figure 5.

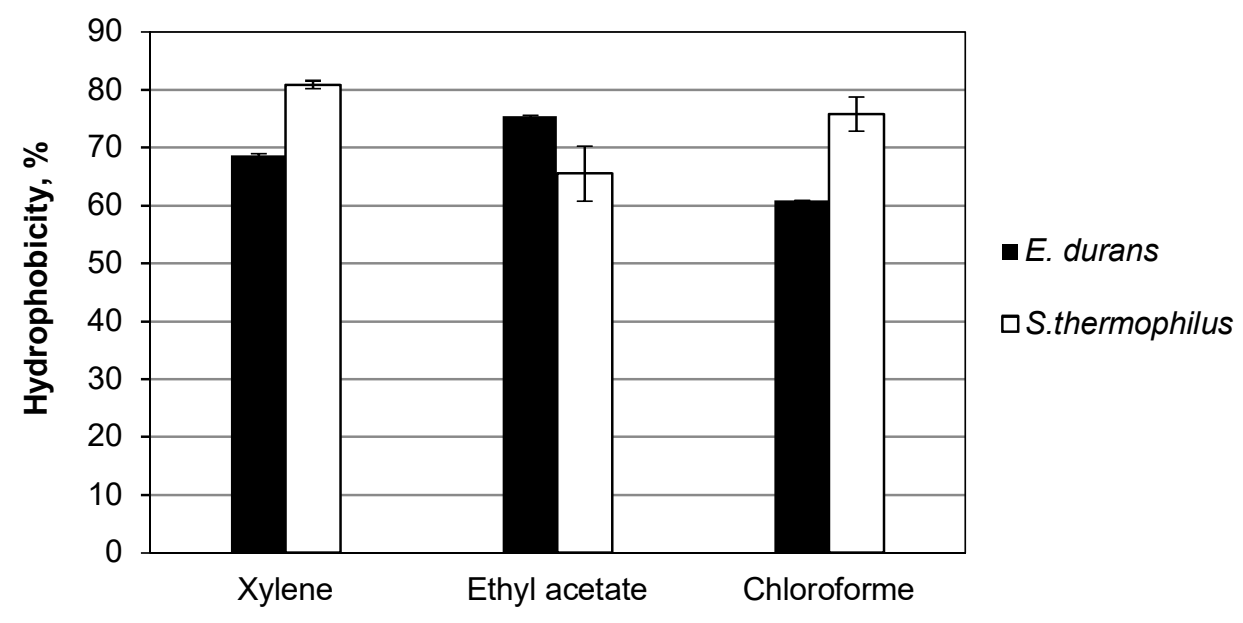

\section{Solvents}

Figure 5. Strains adhesion to solvents

The adhesion percentages to xylene (apolar solvent) were higher than $50 \%$ for the two lactic strains $E$. durans and $S$. thermophilus, i.e. $61 \%$ and $81 \%$, respectively. With ethyl acetate (basic mono-polar solvent), the adhesion rates were around 75 and $77 \%$, for E. durans and $S$. thermophiles, respectively. The percentage of hydrophobicity of cells (using xylene as a solvent) might be classified as strongly hydrophobic ( $>50 \%)$, moderately hydrophobic $(20-50 \%)$ and hydrophilic $(<20 \%)$. According to this classification, S. thermophilus and E. durans can be classified as strongly hydrophobic (Hydrophobicity $>50 \%$ ). The difference in E. durans affinity to the three solvents was highly significant $(\mathrm{P}<0.001)$. Tuncer and Tuncer (2014) also recorded a high affinity (67\%) of S. thermophilus ST8.01 to xylene. Thus in accordance with the results obtained for E. durans, Nami et al. (2019) revealed in their study 
of probiotic characterization and safety assessment of enterococcal isolates from various artisanal dairy products that hydrophobicity values ranged from 23 to $58 \%$, with several isolates recording percentages above 50\%. Ayyash et al. (2018) registered hydrophobicity below 50\% for isolates of the genus Streptococcus and Enterococcus. The higher the aggregation capacity and hydrophobicity, the better the probiotic cells can attach to the epithelial cells thus increasing its efficiency. According to the present study, the percentage of aggregation and hydrophobicity of both strains were higher than $50 \%$. Some reports have indicated that the origin and surface characteristics of the strains may be determinant in the hydrophobicity of their surfaces, generating differences in the affinity of the microbes to various solvents, the majority of probiotic bacteria used as starters show a higher affinity to organic solvents $(>32 \%)$ Vinderola and Reinheimer, 2003). The hydrophobic character of the cell surface is related to the presence of components of protein nature, while hydrophilicity is associated with the presence of polysaccharides (Kos et al., 2003).

Antibiotic resistance. One of the clinical interests of the use of probiotics is the prevention and treatment of antibiotic-associated diarrhea. Thus, the tolerance of probiotics to antibiotics is a desired trait. However, this resistance should not be entrusted to other bacteria. The determination of antibiotic susceptibility of strains intended for safe use in the food sector is a fundamental aspect of the choice to avoid anarchic spread of antibiotic resistance genes through horizontal transfer (Terzić-Vidojević et al., 2015). Antibiotic resistance results are outlined in Table 3.

Antibiotic resistance

Table 3

\begin{tabular}{|lcccc|}
\hline Antibioresistance / Sensibility & & & \\
& $\mathrm{C}_{10}$ & $\mathrm{GM}$ & $\mathrm{AN}_{30}$ & $\mathrm{TE}_{30}$ \\
\hline E. durans & $\mathrm{S}$ & $\mathrm{S}$ & $\mathrm{R}$ & $\mathrm{MS}$ \\
S. thermophiles & $\mathrm{R}$ & $\mathrm{S}$ & $\mathrm{R}$ & $\mathrm{R}$ \\
\hline
\end{tabular}

MS: moderately susceptible, S: susceptible, R resistant.

It is noticeable that the two strains behave differently to the different antibiotics tested. S. thermophilus was sensitive only to gentamicin. In contrast, Enterococcus durans showed significant resistance $(\mathrm{P}-$ values $<0.05)$ to tetracycline and nalidixic acid. Tuncer and Tuncer (2014) reported that $S$. thermophilus ST8.01 exhibited susceptibility to all antibiotics tested including tetracycline, chloramphenicol and gentamicin. Zhou et. al. (2012), evaluating the resistance of some lactic strains to 11 antibiotics, reported that several strains of $S$. thermophilus were resistant to chloramphenicol, only $11 \%$ were sensitive to gentamicin, while $44 \%$ showed resistance to tetracycline. Thus, Tosi et al (2007) showed that $S$. thermophilus strains isolated from various environments were sensitive to all 6 antibiotics tested, including gentamicin, and some were resistant to tetracycline. In a further study, Abamecha et al (2015) indicated that 34\% of Enterococcus isolates exhibited resistance to gentamicin, $64 \%$ to tetracycline, and $34 \%$ to choloramphenicol. According to TerzićVidojević et al. (2015), the presence of antibiotic resistance factors varies between strains and regions. According to the results of their study, 29\% of Enterococcus isolates including Enterococcus durans were susceptible to the antibiotics tested (including gentamicin, tetracycline, and chloramphenicol) and almost $59 \%$ of these isolates were resistant to two or more antibiotics. They reported that out of a total of 636 dairy enterococcal isolates, only five strains under the $E$. durans species have technological potential and meet the safety criteria 
required for use in the dairy industry. The problem of antimicrobial resistance continues to grow worldwide, compromising the effectiveness of the treatment of bacterial infections. The massive use of antibiotics in humans and animals has caused a high probability of developing resistance that could be transmitted through food (Blom and Mørtvedt, 1991; Zhou et al., 2012). Furthermore, the major risk of resistance dissemination is the presence of antibiotic resistance genes on mobile components. Whenever possible, microorganisms used as food additives should be targeted first to the organism with the lowest resistance (Tosi et. al., 2007), which requires further characterization to determine the genetic basis of resistance.

Antagonistic effect. The results of the two lactic strains' antibacterial activity are presented in Table 4.

Table 4

Antibacterial activity of S. thermophilus CNRZ 447 and E. durans NCBI 53345 (intensity according to inhibitory zone)

\begin{tabular}{|c|c|c|}
\hline \multirow{2}{*}{ Lactic strain } & \multicolumn{2}{|c|}{$\begin{array}{c}\text { Antibacterial activity } \\
\text { (intensity according to diameter - mm) }\end{array}$} \\
\cline { 2 - 3 } S. thermophilus & $+++(13,745 \pm 0,72 \% / 10.5-11.5 \mathrm{~mm}))$ & $+++(9,84 \pm 0,542 \% / 7.5-9 \mathrm{~mm})$ \\
\hline E. dueans & $+++(11,875 \pm 2,165 / 8.11 \mathrm{~mm})$. & $+++(9,375 \pm 0,7217 \% / 7-8 \mathrm{~mm})$. \\
\hline
\end{tabular}

(- ) No inhibition, (+) inhibitory zone $0.1-1 \mathrm{~mm}$; (++) inhibitory zone 1.1-2.0 mm; $(+++)$ inhibitory zone $>2.1 \mathrm{~mm}$ (Ayyash et al., 2018).

These results reveal a significant antagonistic activity against the two opportunistic pathogens tested, E. coli and $S$. aureus. The inhibition percentages were $13-9.84 \%$ for $S$. thermophilus and $12-9 \%$ for E. durans against $E$. coli and $S$. aureus respectively. Lactic acid bacteria have always been used in the preservation of food by producing antimicrobial substances. In fact, through fermentation, carbohydrates are reduced into a range of low molecular weight organic molecules such as, acids, lactic, acetic, propionic and ethanol (Blom and Mørtvedt, 1991). Pieniz et al. (2014) reported that E. durans LAB18s displayed a broad spectrum of antimicrobial activity, inhibiting several pathogens such, E. coli and $S$. aureus. Thus, Belgacem et al. (2010) reported that some bacteriocin-producing enterococci isolates reveal many biochemical qualities according to their technological performance in the food industry. Enterocins (bacteriocins) produced by species of the genus Enterococcus are effective against Gram-negative and Gram-positive bacteria. Their resistance to a wide range of temperatures and $\mathrm{pH}$, as well as their broad spectrum of activity, makes them of great technological interest (Tosoni et al., 2019). Akpinar et al. (2011) reported that all $S$. thermophilus strains exhibited antimicrobial activity against $K$. pneumoniae. Besides, $S$. thermophilus strains SL4 and SY2 had an antimicrobial action on all bacteria tested including Staphylococcus aureus and Escherichia coli. Among S. thermophilus strains, some generate a bacteriocin called thermophilin, which is effective against several food spoilage bacteria. Being technologically and biochemically valuable, this bacteriocin is conceivable as a potent biopreservative (Aktypis et al., 2007). Also, Enterococcus, Lactococcus and Pediococcus, are also among the lactic acid bacteria frequently applied as natural preservatives, due to their potential production of metabolites with antimicrobial properties, including organic acids, hydrogen peroxide, antimicrobial enzymes and bacteriocins (Wu et al., 2014). 
Exopolysaccharides production. The yield of EPSs produced by the two lactic strains is elucidated in Table 5.

EPS productivity of S. thermophilus CNRZ 447 and E. durans NCBI 53345

Table 5

\begin{tabular}{|c|c|}
\hline Lactic strains & $E P S(m g / L)$ \\
\hline E. durans & $1661 \pm 27^{a}$ \\
\hline S. thermophilus & $176 \pm 4^{\mathrm{a}}$ \\
\hline
\end{tabular}

S. thermophilus, which is a strain generally used for its technological qualities as a starter, was found to be less productive of EPSs than E. durans ( 176 vs $1661 \mathrm{mg} / \mathrm{L}, \mathrm{P}<0.05$ ). The performance obtained was comparable to the maximum EPS yield of $S$. thermophilus species (Abdellah et al., 2015; Kanamarlapudi and Muddada, 2017). In agreement with our previous study (Boubakeur et al., 2018), the level of EPSs produced by S. thermophilus was $200 \mathrm{mg} / \mathrm{L}$. It was possible to significantly improve the yield from 200 to $826 \mathrm{mg}$ glucose/ L, adopting as an approach, the polyphenolic extract of Thymus fontanesii. Abdellah et al. (2015) in their study evaluating biofilm formation by thermophilic EPS+ lactic acid bacteria noted that the EPS levels of enterococci were 0.07 and $0.242 \mathrm{~g} / \mathrm{L}$, the fewest of all isolated lactic acid strains. Besides, Mostafa et al (2009) reported that for one Enterococcus species, the maximum EPS production after 6 hours of fermentation was $23 \mathrm{~g} / \mathrm{L}$.

HPLC profile of the produced exopolysaccharides. The HPLC profile of the EPS produced by $S$. thermophilus CNRZ 447 (previously published profile, Khadem et al., 2020) and $E$. durans is presented in Figure 6 (A, B) and 7 (C, D) respectively.

Chromatograms "A and B" revealed that the EPS generated by S. thermophilus CNRZ 447 was composed mainly of two triholosides predominantly consisting of glucose. The exact monosaccharide composition was insufficiently determined. However, S. thermophilus species is reported to produce heteropolysaccharides (Kanamarlapudi and Muddada, 2017). On the other hand, EPS produced by E. durans revealed peaks at 7 and 9 min that corresponded to oligosaccharides, and a single peak, resulting from elution at $20.4 \mathrm{~min}$, that probably corresponded to sorbitol. The EPSs produced by lactic bacteria display very varied structures. Indeed, the composition in monosaccharides, the links between the units, the presence of repeated side chains and substitutions are often at the origin of divergences between the EPSs. However, the structural characterization of the produced polymers still requires a more detailed identification. 

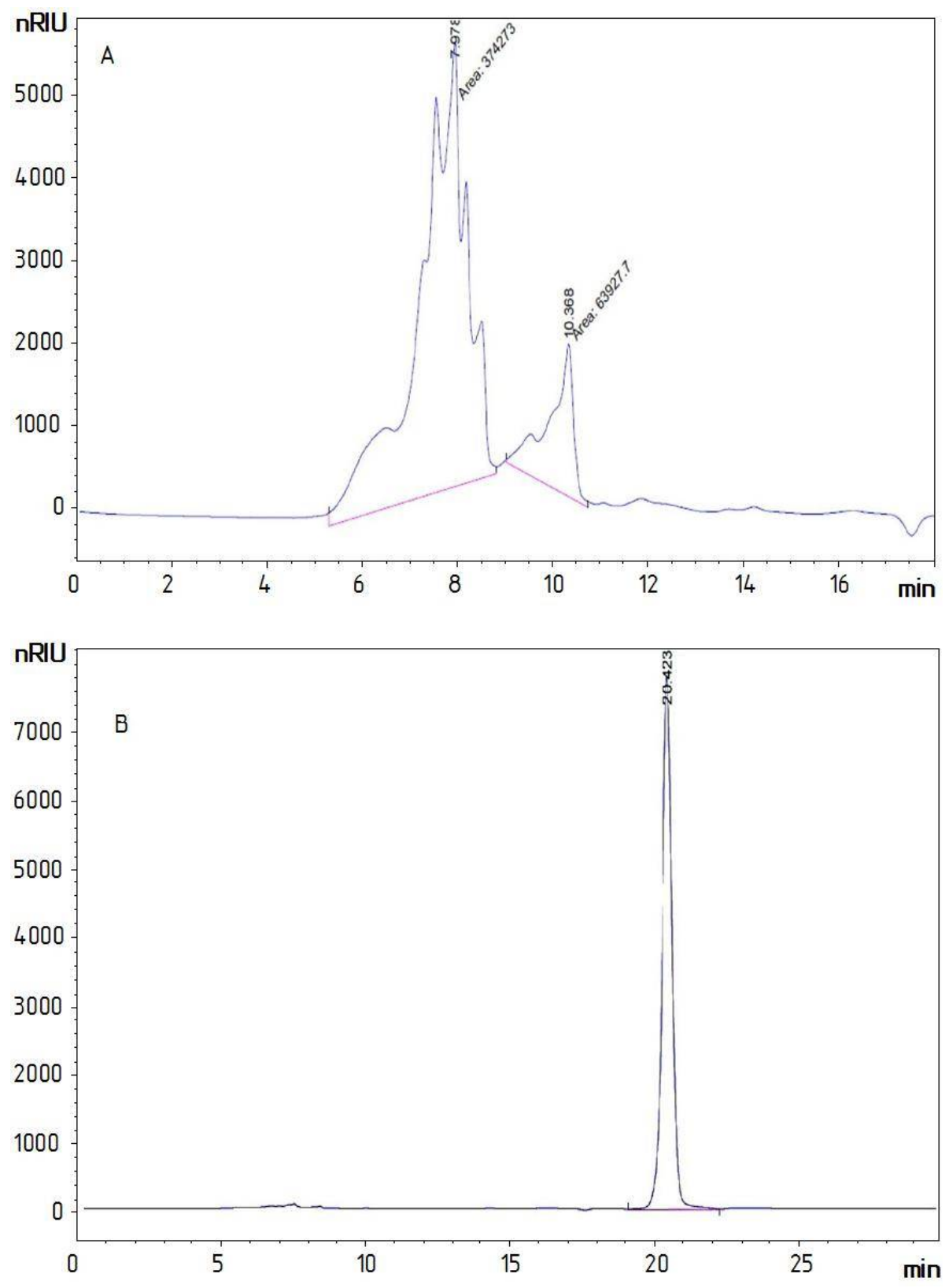

Figure 6. HPLC profile of the EPS of S. thermophilus CNRZ 447 [56]:

$A$ - the two distinct triholosides (between 7 and 10 minutes residues.

B - a single characteristic peak at 20.4 minutes was observed for the hydrolyzed EPS. 

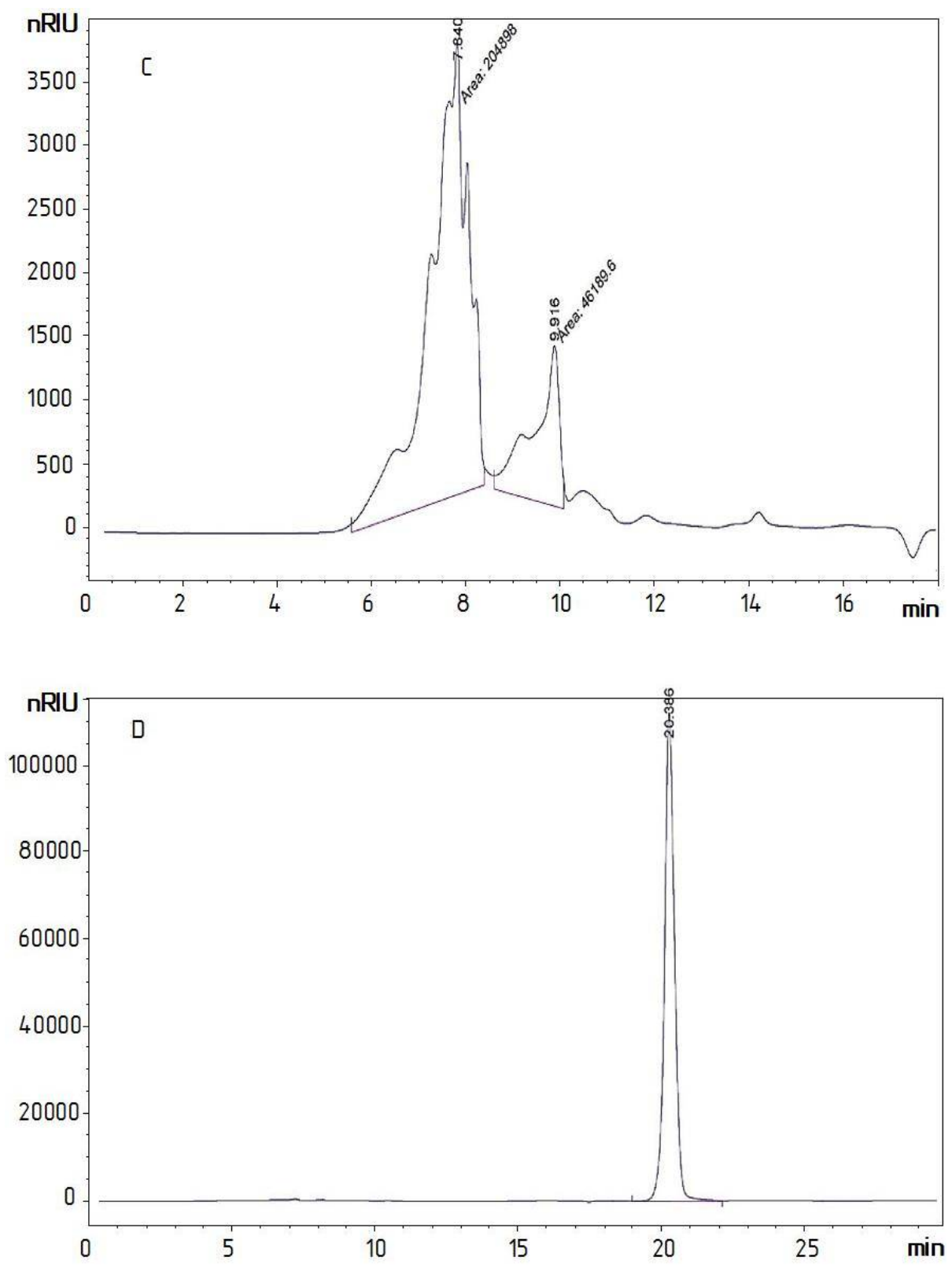

Figure 7. HPLC profile of $E$. durans NCBI 53345 EPS:

C - The EPS oligosaccharides (between 7 and 9 minutes).

D - a single characteristic peak at $\mathbf{2 0 . 3}$ minutes observed for hydrolyzed EPS. 


\section{Conclusion}

1. The in vitro study revealed that both E. durans NCBI 53345 and S thermophilus CNRZ 447 strains have a promising probiotic potential.

2. Exopolysacchrides production and specific characterizing of these strains contribute to the protection of microbial cells against extreme environments (temperature variation, low $\mathrm{pH}$ and bile salts).

3. The strains investigated could be recommended as potential culture starter and probiotics.

The in vitro study revealed that the two strains $S$. thermophilus CNRZ 447 and E. durans NCBI 53345 have a promising probiotic potential. Thus, according to the findings of the probiotic potential assessment of the two lactic strains, it is suggested that the production of the exopolysaccharides characterizing these two strains potentially contributes to their protection against extreme environments (temperature variation, low $\mathrm{pH}$ and bile salts). Indeed, this investigation has allowed supposing that the high production of EPS can be a pivotal trait in the screening of probiotic strains.

Acknowledgment. The experimental research was mainly carried out in alternation in the research laboratory "Bioconversion, Microbiological Engineering, and Sanitary Safety" (BGMSS) of the Natural and Life Sciences Faculty of Mascara University and the laboratories of Biochemistry and Microbiology of the Natural and Life Sciences Faculty of Tiaret University. The identification of $E$. durans, was made at the Center for Scientific and Technical Research in Physical and Chemical Analysis (CRAPC) in Bous-Ismail, Tipaza, Algeria. The chromatographic analysis of exopolysaccharides was carried out in the research center of Trakya University, Edirne-Turkey. The authors express their thanks and gratitude to the directors and staff of these laboratories and research centers.

\section{References}

Abamecha A. Wondafrash B., Abdissa, A. (2015), Antimicrobial resistance profile of Enterococcus species isolated from intestinal tracts of hospitalized patients in Jimma, Ethiopia, BMC Research Notes, 8(1), pp. 1-7.

Abdellah M., Ahcène H., Benalia Y., Saad B., Abdelmalek B. (2015), Evaluation of biofilm formation by exopolysaccharide-producer strains of thermophilic lactic acid bacteria isolated from Algerian camel milk, Emirates Journal of Food and Agriculture, pp. 513521.

Akers K.S., Cardile A. P., Wenke J. C., Murray C. K. (2015), Biofilm Formation by Clinical Isolates and Its Relevance to Clinical Infections. [In:] Biofilm-based Healthcareassociated Infections Volume I, G. Donelli), pp. 193, 1-28.

Akpinar A., Yerlikaya O., Kiliccedil S. (2011), Antimicrobial activity and antibiotic resistance of Lactobacillus delbrueckii ssp. bulgaricus and Streptococcus thermophilus strains isolated from Turkish homemade yoghurts, African Journal of Microbiology Research, 5(6), pp. 675-682.

Aktypis A., Tychowski M., Kalantzopoulos G. and Aggelis G. (2007), Studies on bacteriocin (thermophilin T) production by Streptococcus thermophilus ACA-DC 0040 in batch and fed-batch fermentation modes, Antonie van Leeuwenhoek, 92(2), pp. 207-220.

Andrew J.M. (2008), BSAC standardized disc susceptibility testing method (version 7), Journal of Antimicrobial Chemotherapy, 62, pp. 256-278. 
Anukam K. C., Koyama, T. (2007), Bile and acid tolerance of Lactobacillus plantarum KCA1: A potential probiotical agent, International Journal Dairy Science , 2 (3), pp. 275280.

Auffray Y., Lecesne E., Hartke A., Boutibonnes P. (1995), Basic features of the Streptococcus thermophilus heat shock response, Current Microbiology, 30(2), pp. 8791.

Ayyash M., Abushelaibi A., Al-Mahadin S., Enan M., El-Tarabily K., Shah, N. (2018), Invitro investigation into probiotic characterisation of Streptococcus and Enterococcus isolated from camel milk, $L W T, 87$, pp. 478-487.

Bagci U., Togay S. O., Temiz A., Ay, M. (2019), Probiotic characteristics of bacteriocinproducing Enterococcus faecium strains isolated from human milk and colostrum, Folia Microbiologica, 64(6), pp. 735-750.

Balouirin M. Sadiki M. and Ibnsouda S. K. (2016), Methods for in vitro evaluating antimicrobial activity: A review, Journal of Pharmaceutical Analysis, 6(2), pp. 71-79.

Bauer A. W. (1966), Antibiotic susceptibility testing by a standardized single disc method, Am J clin pathol, 45(4), pp. 149-158.

Begley M., Gahan C. G., Hill C. (2005), The interaction between bacteria and bile, FEMS microbiology reviews, 29(4), pp. 625-651.

Belgacem Z. B., Abriouel H., Omar N. B., Lucas R., Martínez-Canamero M., Gálvez A., Manai, M. (2010), Antimicrobial activity, safety aspects, and some technological properties of bacteriocinogenic Enterococcus faecium from artisanal Tunisian fermented meat, Food Control, 21(4), pp. 462-470.

Blom H., Mørtvedt C. (1991), Anti-microbial substances produced by food associated microorganisms, Biochemical Society Transactions, 19(3), pp. 694-698.

Bogsan C. S., Nero L. A., Todorov S. D. (2015), From Traditional Knowledge to an Innovative Approach for Bio-preservation in Food by Using Lactic Acid Bacteria. [in:] Beneficial Microorganisms in Food and Nutraceuticals, Ed Liong M.T, London, Springer, pp. 2-28.

Boke H., Aslim B., Alp G. (2010), The role of resistance to bile salts and acid tolerance of exopolysaccharides (EPS) produced by yogurt starter bacteria, Archives of Biological Sciences, 62(2), pp. 323-328.

Boris S., Suarez J. E., Barbes C. (1997), Characterization of the aggregation promoting factor from Lactobacillus gasseri, avaginal isolate. Journal of applied microbiology, 83(4), pp. 413-420.

Boubakeur B., Drobo S. M., Khadem H., Mullier C., Tirtouil A. (2018), Influence of the exopolysaccharides of polyphenol-conditioned lactic acid bacteria on gut microecology and bacterial translocation, Ukrainian Journal of Ecology 8(3), pp. 1-9.

Chen W., Yu L., Shi Y. (2019), Safety Evaluation of Lactic Acid Bacteria. [in:] Lactic Acid Bacteria: Omics and Functional Evaluation, Chen W, Singapore: Springer, pp. 371409.

Charteris W. P., Kelly P., M., Morelli L., Collins J. K. (1998), Development and application of an in vitro methodology to determine the transit tolerance of potentially probiotic Lactobacillus and Bifidobacterium species in the upper human gastrointestinal tract, Journal of applied microbiology 84(5), pp. 759-768.

Collado C. M. (2009), Role of probiotic in health and diseases. [In:] Handbbok of probiotic and prebiotic, $2^{\text {nd }}$ ed. Y.K Lee and S. Salminen, p. 608, pp. 257-350. John Wiley et Sons.

Cowan S. T. (2004), Manual for the identification of medical bacteria, Barrow G. I., FelthamR. K. A, New York. Cambridge university press, pp. 21-42. 
Drabo M. S., Khadem H., Benatmane N. E., Ouhab A., Zohra M. F., Soualmi K., Boubakeur B. (2019), Qualité microbiologique du blé dur fermenté de Matmor Hamoum: Indispositions digestives, microflore avantageusement technologique et potentiels pathogènes, International Journal of Innovation and Applied Studies, 27(1), pp. 11-18.

Dressman J. B., Berardi R. R., Dermentzoglou L. C., Russell T. L., Schmaltz S. P., Barnett J. L., Jarvenpaa K. M. (1990), Upper gastrointestinal (GI) pH in young, healthy men and women, Pharmaceutical research, 7(7), pp. 756-761.

Dubois M., Gilles K. A., Hamilton J. K. , Pebers P. A., Smith F. (1956), Colorimetric method for determination of sugars and related substances. Analytical Chemistry, 28(3), pp. 350-356.

Fang Q. H., Zhong J. J. (2002), Submerged fermentation of higher fungus Ganoderma lucidum for production of valuable bioactive metabolites ganoderic acid and polysaccharide, Biochemical Engineering Journal 10(1), pp. 61-65.

FAO/WHO (2001), Health and nutritional properties of probiotics in food including powder milk with live lactic acid bacteri, Report of a joint FAO/WHO expert consultation.

Gousia P., Economou V., Sakkas H., Leveidiotou S., Papadopoulou C. (2011), Antimicrobial resistance of major foodborne pathogens from major meat products, Foodborne pathogens and disease, 8(1), pp. 27-38.

Gregirchak N., Stabnikova O., Stabnikov V. (2020) Application of lactic acid bacteria for coating of wheat bread to protect it from microbial spoilage, Plant Foods for Human Nutrition, 75, 223-229.

Haddaji N., Krifi B., Lagha R., Khouadja S., Bakhrouf A. (2015), Effect of high temperature on viability of Lactobacillus casei and analysis of secreted and Groel proteins profiles, African Journal of Bacteriology Research, 7(3), pp. 29-35.

Jobin M. P., Delmas F., Garmyn D., Divies C., Guzzo J. (1998), Caractérisation des protéines de choc thermique de faible poids moléculaire chez les bactéries lactiques, Le Lait, 78(1), pp. 165-171.

Kanamarlapudi S.L.R.K., Muddada, S. (2017), Characterization of exopolysaccharide produced by Streptococcus thermophilus CC30. BioMed Research International, pp. 111.

Khadem H., Tirtouil A., Drabo M. S., Boubakeur, B. (2020), Influence of ultrasounds conditioning on biotechnological performances of the lactic acid bacteria stain streptococcus thermophilus CNRZ 447: growth, exopolysaccharides, biofilm, and aggregation, Biotechnologia, 101(2), pp. 159-165.

Kos B. Suskovic J., Vukovic S., Simprag M., Frece J., Matosic S. (2003), Adhesion and aggregation ability of probiotic strain Lactobacillus acidophilus M92, Journal of Applied Microbiology, 94, pp. 981-987.

Lee K., Lee H.G., Choi Y.J. (2008), Proteomic analysis of the effect of bile salts on the intestinal and probiotic bacterium Lactobacillus reuteri. Journal of Biotechnology, 137(1-4), pp. 14-19.

Li M., Wang Y., Cui H., Li Y., SunY., Qiu H. J. (2020), Characterization of lactic acid bacteria isolated from the gastrointestinal tract of a wild boar as potential probiotics, Frontiers in veterinary science, 7(49), pp. 1-10.

Lim B., Gross C. A. (2011), Cellular response to heat shock and cold shock. [in:] Bacterial Stress Responses, Storzg, G., Hengge, R. Washington, ASM Press,pp. 91-114.

Mostafa H., El-Mezawy A., Geis A., Heller, K. J. (2009), Exopolysaccharide production by Enterococcus faecium. Milchwissenschaft, 64(4), pp. 361-365. 
Mulaw G. Sisay T., Muleta D., Tesfaye A. (2019), In vitro evaluation of probiotic properties of lactic acid bacteria isolated from some traditionally fermented Ethiopian food products, International journal of microbiology, pp.1-32.

Nami Y., Vaseghi Bakhshayesh R., Mohammadzadeh Jalaly H., Lotfi H., Eslami S., Hejazi M. A. (2019), Probiotic Properties of Enterococcus Isolated From Artisanal Dairy Products, Frontiers in Microbiology, 10 (300), pp. 1-13.

O'Grady B., Gibson G. R. (2005), Microbiota of the human gut. [in:] Probiotic Dairy Products, Ed. Tamime, Adnan Y.Oxford, Blachwell, pp. 1-15.

Oleksy-Sobczak M., Klewicka E. (2019), Optimization of media composition to maximize the yield of exopolysaccharides production by Lactobacillus rhamnosus strains, Probiotics and antimicrobial proteins, pp. 1-10.

Pavlovic M., Huber I., Konrad R., Busch U. (2013), Application of MALDI-TOF MS for the Identification of Food Borne Bacteria, The Open Microbiology Journal, 7(1), pp. 135141.

Pieniz S., Andreazza R., Anghinoni T., Camargo F., Brandelli A. (2014), Probiotic potential, antimicrobial and antioxidant activities of Enterococcus durans strain LAB18s, Food Control, 37, pp. 251-256.

Růžičková M., Vítězová M., Kushkevych I. (2020), The characterization of Enterococcus genus: resistance mechanisms and inflammatory bowel disease, Open Medicine 15(1), pp. 211-224.

Terzić-Vidojević A., Veljović K., Begović J., Filipić B., Popović D., Tolinački M., Golić, N. (2015), Diversity and antibiotic susceptibility of autochthonous dairy enterococci isolates: are they safe candidates for autochthonous starter cultures, Frontiers in Microbiology, 6, (954), pp. 1-10.

Tosi E. A., Ortega R.M.E., Cazzoli, A. F. (2007), Food preservative based on propolis: Bacteriostatic activity of propolis polyphenols and flavonoids upon Escherichia coli, Food chemistry 104, pp. 1025-1029.

Tosoni N. F., Perini H. F., Terra M. R., Katsuda M. S., Furlaneto M. C., Maia L. F. (2019), Antimicrobial activity of enterocin obtained from Enterococcus durans on Shiga-like toxin-producing Escherichia coli, Ciência Rural, 49(9), pp. 1-7.

Tuncer B. Ö., TuncerY. (2014), Exopolysaccharide producer Streptococcus thermophilus ST8. 01 strain. A potential probiotic culture, GIDA/The Journal of FOOD, 39(4), pp. 195-202.

Varmanen P., Savijoki K. (2011), Responses of lactic acid bacteria to heat stress. [in:] Stress responses of lactic acid bacteria, Tsakalidou, E., Tsakalidou, k, London,Springer, pp. 55-66.

Vinderola C. G., Reinheimer J. A. (2003), Lactic acid starter and probiotic bacteria: a comparative "in vitro" study of probiotic characteristics and biological barrier resistance, Food Research International, 36(9-10), pp. 895-904.

Wu Q., Tun H. M., Leung F. C. C., Shah N. P. (2014), Genomic insights into high exopolysaccharide-producing dairy starter bacterium Streptococcus thermophilus ASCC 1275, Scientific reports, 4(1), pp. 1-8.

Xu H., Jeong H. S., Lee H. Y., Ahn, J. (2009), Assessment of cell surface properties and adhesion potential of selected probiotic strains, Letters in applied microbiology, 49(4), pp. 434-442.

Zhou N., Zhang J. X., Fan M. T., Wang J., Guo G., Wei X. Y. (2012), Antibiotic resistance of lactic acid bacteria isolated from Chinese yogurts, Journal of dairy science, 95(9), pp. $4775-4783$. 